\title{
Impact of climate change on the Distribution behavior of Alkanna orientalis in Saint Catherine, south Sinai, Egypt
}

\author{
Abdelraouf A. Moustafa* and Samira R. Mansour \\ Botany department, Faculty of Science, Suez Canal University, Ismailia
}

\begin{abstract}
Alkanna orientalis is a medicinal plant with great importance as traditional medicine. Its distribution and population are considered significance for conservation of such plant to obtain the greatest benefit for the present generation and maintaining the potential for future. Many factors are playing a role in conserving the plant in a good condition; climate change is one among these factors. Therefore, our study is focusing on the impact of climate change on the distribution of Alkanna orientalis in the main growing area in Saint Catherine, Egypt. To address the influence of climate change and have a better understanding of the stress that can affect or cause extension of Alkanna plant from its main habitats, studying the actual state of plant community and its distribution along last decade will give a predicting thought for its behaviour and distribution pattern. Develop a promising strategy for dynamic conservation of Alkanna plant will be discussed.
\end{abstract}

Keywords: Climate change, Alkanna distribution, conservation strategy, Saint Katherine.

\section{INTRODUCTION}

Alkanna Orientalis (L.) Boiss. is one of the most important medicinal plants belongs to family Boraginaceae. The family has many different genera of at least a hundred-fifty genera (Ning et al., 1994). There are two main species of Alkanna recorded in Egypt. They grow as wild plants in the Egyptian desert; the first species is A. orientalis (L.) Boiss and known as Libbid or Lebbed, as common name. The second species is A. tinctoria and known as Henna El-Ghoul (Täckholm, 1974). Boraginaceae is a comparatively large family, ranging from annual to perennial herbs, shrubs and trees. About 30 genera are used as decorative and many of species are of medicinal value (Heywood et al., 1978. Abdel-Gelil, 2019). However, roots of some species are used in industrial purpose as a dye. Boraginaceae is distributed mainly throughout moderate and subtropical areas and less frequent in cool moderate and tropical regions. In Egypt, nineteen genera of this family were recorded (Täckholm, 1974, Moustafa et al., 2017). Twenty-seven species out of fifty-two species were recorded in Sinai (Moustafa et al., 2017).

Several phytochemical studies were done on different species of Alkanna (Vorvagalis, 1972; Afzal and Tofeeq, 1975; Papageorgiou, 1980, Abdel-Gelil et al., 2019) which clarified the medical importance of this plant. However, focusing on direct interactions between plant and other organisms, which may influence on the construction of ecological concept and evaluate the dynamics and structure of the plant communities, Semida (1994) studied the insectplant interaction from the pollination point of view. He discovered that Anthophora bees have certain structural attributes, enabled them to exploit and collect the floral nectar from the tubular corolla of Alkanna orientalis flower. Therefore, there is a potential for indirect effect on the plant in its community, as well as the interactions where they also establish. This indirect ecological effect may play an important role as a developing property of the natural communities of the plant.

In fact, not many ecological studies have been done concerned the autoecology of Alkanna orientalis except that study by Moustafa (2001). In his study, he focused on the effect of grazing intensity and human disturbance on the population dynamics of Alkanna orientalis in Saint Catherine area. He found that overgrazing caused a significant change in Alkanna plant communities. Meanwhile, in another study done by Moustafa and Kamel, (1995), they recorded a marked change in plant populations with the appearance of some species indicative of overgrazing such as Alkanna orientalis, Peganum harmala, Phlomis aurea and Fagonia mollis. Effect of climate change on plant communities and their behaviour has not clearly explored. Therefore, this study was aimed to give an attention on the climate change effect on the distribution behavior of Alkanna through the environmental gradients and discuss the reasons of the vegetation of Alkanna which is very restricted to these narrow and closed wadis of Saint Catherine.

\section{Morphology of Alkanna}

Alkanna orientalis is herbaceous perennial plant native to Mediterranean countries including Egypt. It characterized by lanceolate hairy leaves with glandular hairs; stem is branching above the base with average internode length of $0.7-1.6 \mathrm{~cm}$. Leaves are dense subsessile to sessile with alternate arrangement on the stem. Basal leaves are 5.5-6.5 x 1.2-1.4 cm long. Cauline leaves are 2.2-2.8 x 0.3-0.5 cm long. The citrus-scented leaves give rise to dense, mounding, self-mulching tops studded with long-lasting, deeply golden yellow flowers (Figure 1). The root of the plant is taproot in shape with pale-brown hard bark is present. Bracts are lanceolate to ovate, 1-6 $\times$ 0.5-2.5 $\mathrm{cm}$. Corolla 7.5-10 $\mathrm{mm}$ in length with glabrous texture outside and limb sulphur yellow 5-lobed in colour. Anthers are 2-3.5 mm long with filaments $0.5-1 \mathrm{~mm}$ 
long. Nutlets are 4-6 mm in diameter and covered with tuberculate, beak strongly deflexed (Figure 1).

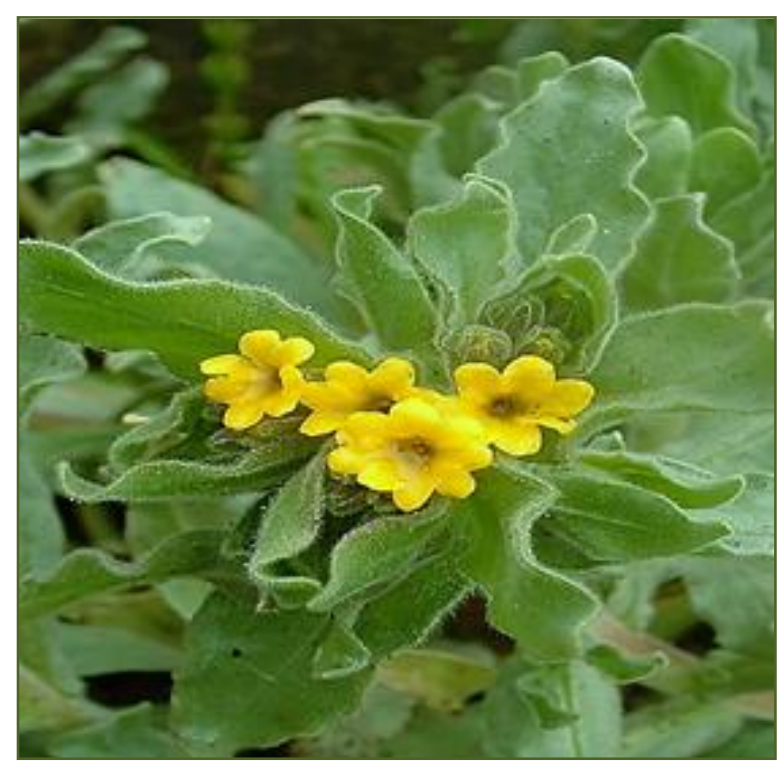

Figure (1): Photomicrograph showing morphological features of Alkanna orientalis, grows in Wadi El-Arbaie'en, Saint Catherine area, presenting the hairy leaves and yellow lobed Corolla.

\section{Seed germination}

Akanna seeds are germinating in constant moisture condition (not wet) with temperatures of about $+20^{\circ} \mathrm{C}$. The seedling stage is the most vulnerable and is usually accompanied by extremely high mortality (Harper, 1983) while the seed stage is uniquely resistant to various environmental stresses. Since germination links these two stages showing such great difference risk in levels, any physiological mechanism confining germination only to circumstances associated with a high probability of sound seedling establishment would have a great adaptive value (Washitani and Kabaya, 1988). Therefore, the germination behavior of Alkanna was interesting to be addressed (Moustafa, 2002). In his study the seeds of Alkanna have a very strong dormancy even with different treatments applied; one could reach only $35 \%$ as a maximum percent of germinated seeds at consistent soil moisture content. The greatest germination percentage was obtained when combination of temperature and light was applied. Based on this combination two degrees of temperature, $5^{\circ} \mathrm{C}$ and $20^{\circ} \mathrm{C}$ combined with light off and on, respectively, recorded the highest germination percentage. These results attributed the distribution of this species to very restricted area of those very closed and shaded wadies in Saint Catherine area and nothing else mentioned about the effect of climate change at that time.

In general, Saint Catherine area is characterized by very sparseness of plant cover, a limited number of plant species, associations and paucity of trees (Moustafa and Zaghloul, 1996). The rocky land formhabitats of this region permit the root of the adapted species, such as Alkanna orientalis, to penetration the shallow soils with low water content and support the plant growth (Moustafa and Zaghloul, 1996).

\section{Pharmacological effects}

The major component of Alkanna sp. is alkannin and its derivatives, besides alkaloids, flavonoids and other secondary compounds which play an important role in human health (Zannou and Koca, 2020; Abel Elglil et al., 2019; Mita et al., 1994 and Hammouda et al., 1992). The upper surface of the root contains an isohexenyl naphthazarin compound belongs to red naphthoquinone pigments plus to another isomer, known as shikonin (Tanaka and Odani, 1972) which widely used in industrial purposes.

According to that study by (Lev and Amar, 2000) Alkanna orientalis leaf and flower extract inhibited the growth of Staphylococcus aureus, Alkanna orientalis (L.) Boiss (Boraginaceae) produces an antimicrobial agent called sarothrin against Staphylococcus aureus and Mycobacterium smegmatis. This plant genus was traditionally employed as a treatment for digestive problems and for wound healing. Bioassay-guided fractionation of Alkanna orientalis resulted in the isolation of the flavonoid sarothrin (5, 7, 4'-trihydroxy3, 6, 8-trimethoxyflavone). Sarothrin was observed to inhibit $M$. smegmatis (MIC $75 \mu \mathrm{M}$ ) and weakly inhibited S. aureus growth [MIC $>800 \mu \mathrm{M}, 50 \%$ inhibition of growth at $38 \mu \mathrm{g} / \mathrm{mL}(100 \mu \mathrm{M})$. However, the crude A. orientalis leaf and flower extract, which contained only $1.63 \pm 0.13 \%$ sarothrin, had very similar activity to that of sarothrin alone.

\section{Habitat description}

Alkanna grows in St. Catherine area (South Sinai) at an elevation of 1500 to 2624 m.a.s.l. (Figure 1) which includes the main mountains in the area, Gebel ElRabah (1800 m), Gebel Safsafa (1800 m), Gebel Mousa $(2285 \mathrm{~m})$ and Gebel Catherine which represents a series of mountains at different elevations with large valleys, (W. El-Esbae'a, W. Rutig, W. El-Arbaie'en and W.Tala'a). In St. Catherine area, Alkanna orientalis L. (Boiss) has specific pattern of growth where it grows in wadis in scattered patches of different size separated by rocky boulders. The population growth of Alkanna is also limited by habitat size. It starts flowering early in the spring season in late March which is the only plant blooms in that time. Solitary Anthophora bees emerge at about the same time, and are the only insect flower visitors in that time; during the second half of the flowering season in May-June they share visitation to these flowers with other visitors.

Generally, Saint Catherine area was described as predominantly smooth-faced granite outcrops forming mountains such as Gebel Serbal and Gebel Ras Safsafa (Said, 1962). Mostly, the area is formed of igneous and metamorphic rocks, chiefly granites are intensely dissected and rugged (Said, 1962). The geomorphology of Saint Catherine area forms a part of highly rugged mountains with acid plutonic and volcanic rocks belong to the Precambrian basement complex of the southern part of Sinai Peninsula. The landscape of the 
study area has four landform types, slopes, gorges, terraces and ridges (Figure1). The mountains of this area are dissected by faults and joints that play an important role in the moment of the ground water (Moustafa and Klopatek, 1995). Saint Catherine area represents the highest part of southern Sinai mountainous terrain. Typically, Saint Catherine is characterized by high and rugged mountains that range in height between 1500 and 2641 meters above sea level (a.s.l). Mountains are dissected by faults and joints which play and important role in controlling the movement of ground water (Moustafa and Klopatek, 1995).

\section{Climate}

South Sinai is characterized by an arid to extremely arid climate with long hot rainless summer and mild winter. However, due to the wide range of altitude, there is a wide range of variation in air temperature. The data recorded represent an evidence for the rapid climate change in the Saint Catherin area, Sinai, Egypt. Data analyses for temperature, humidity and rainfall from 2010 to 2020 showed a clear tendency towards decreasing rainfall and increasing average temperatures. This tendency along time will cause severe droughts that affect the plant growth and their pattern of distribution. On condition that this tendency last, the population dynamics of many plant and animal species will be negatively affected, with many of them being important for local inhabitants.

In comparison with the climate of Saint Catherine area during the studied years revealed that the mean annual precipitation in Saint Catherine area over 25 years (1970-1994) was $45 \mathrm{~mm}$ per year; the high mountains receive more precipitation (100 $\mathrm{mm} /$ year) as rain and snow verses to $4 \mathrm{~mm}$ during 2010-2020 of the entire year and the collects was up to $21 \mathrm{~mm}(0.8 ")$ of precipitation (Figure 2). However, the average temperature increased and recorded $32^{\circ} \mathrm{C}$ in summer and $15.8^{\circ} \mathrm{C}$ in winter verse to the extremes of the mean recorded temperature range from 5.4 (the lowest temperature in January and February) to $25.1^{\circ} \mathrm{C}$, the highest temperature in July and August, during the year of 1970 to1994 (Moustafa and Kamel 1995).

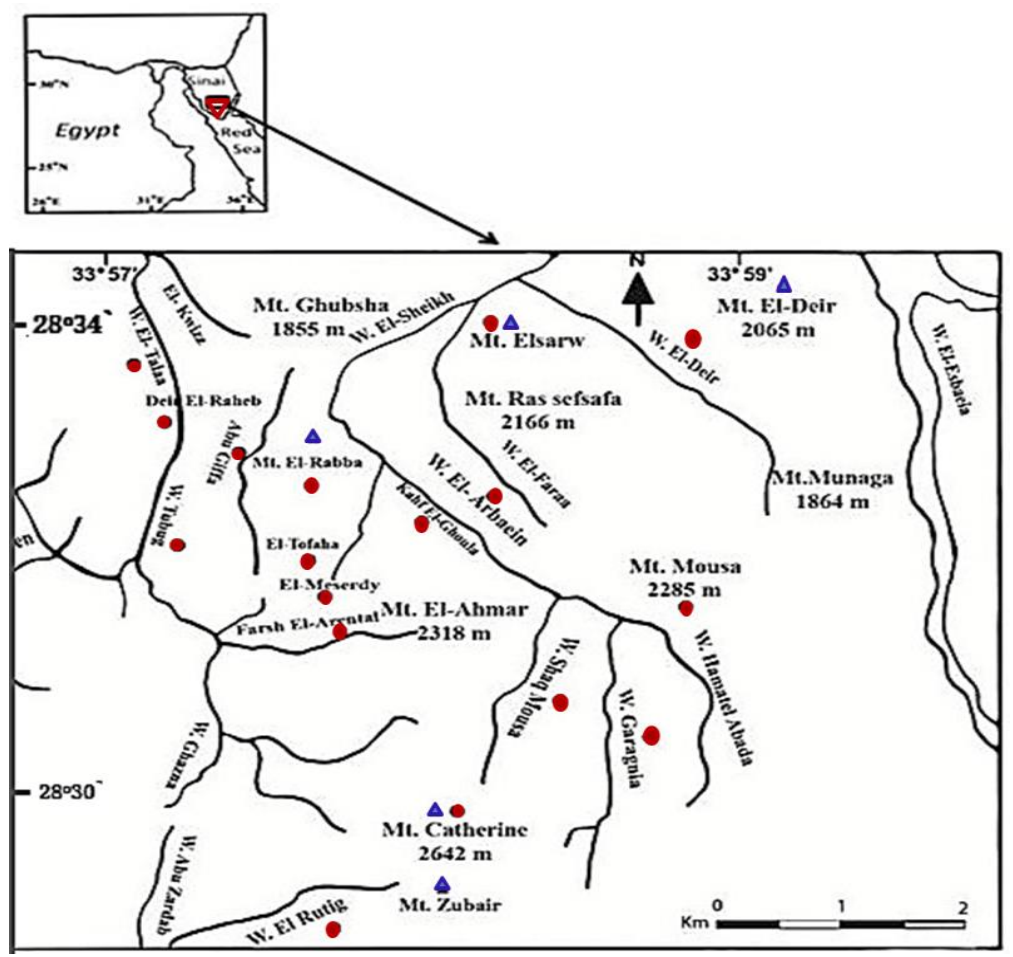

Figure(2): Location map of Saint Catherine area showing the most favorable habitats where Alkanna orientalis occurred with a high dominant population dynamic that restricted to closed wadis.

\section{Climate change and Flora of Saint Catherine area}

The unique location of Sinai, as a mediated part between Africa, Europe, and Asia, gives a distinctive weather than those of Delta area of Egypt. Therefore, the weather is fluctuated, from time to time, between warmer and cooler climate that affect deeply on the vegetation. In general, the flora of Sinai is composed of new common and widespread semi shrubs and shrubs, and many rare species which have a limited distribution in time and space. The pattern of dominated plant groups varies from mangrove forest to high mountainous shrubs. In most areas, the vegetation is sparse, but there are no vegetation-free desert areas. The vegetation diversity of Sinai within this pattern is great and significant. Thirty-nine of those species are endemic, being found in nowhere else in the world but 
Sinai. The vegetation is characterized by the dominance of four large families, namely compositae, leguminosae, labiatae, and cruciferae. These families are represented in Sinai by a large number of endemic plant species (Moustafa et al., 2017).

St. Catherine area has a special characteristic flora with a wide variety of wild plants, due to its unique climatic condition. Some of them have an economic importance which strictly inaugurate to areas up on the mountains or on the rocky slope of the mountains, while others grow in the Wadi bed. Economically, the most important plants in St. Catherine area are Ballota undulate, Menthe longifolia, M. microphylla, Origanum syriacum, Stachys aegyptiaca (all labiatae), Achillea fragrantissima, Artemisia inculta, Artemisia judaica, Tanacetum santoliniodes (compositae), Fgonia mollis, Peganum harmala (Zygophyllacaea) and Alkanna orientalis (boraginaceae). In addition, editable fruit trees are grown or planted in isolated patches along the different wadis of St. Catherine (e.g. Ficus pseudosycomorus, Olea europaea, Prunus amygdalus, Prunus armeniaca, and Prunus domestica, Prunus mols, Prunus persica, Tamarix sp., and Vitis vinifera). These fruit trees are blooming in early spring, while most of the wild plants flower in late spring and summer.

In the study site, Wadi El-Arbaie'en, the vegetation is made up of plants that are numerous in number of species, but few in number of individuals of each species. They are found in different patches of habitat isolated or semi -isolated from each other in different localities of the Wadi. The most common plants are:

Family: Asclepiadaceous (Gomphocarpus sinaicus Boiss.).

Family: Boraginaceae (Alkanna orientalis (L.) Boiss.).

Family: Compositae (Achillea fragrantissima (forssk.) Sch-Bip, Artemisia inculta Del., Echinopis glaberrimus Dc. Onopordum ambiguum., Tanacetum santolinoides Dc.).

Family: Cruciferae (Diplotaxis harra (forssk.), Boiss. Zilla spinosa (L.) Prantl.).

Family: Labiatae (Ballota undulate (fresen.) Benth., Menthe longifolia (L.), Origanum syriacum L., Phlomis aurea decne., Salvia spinosa L., Stachys aegyptiaca Pers.).

Family: Scrophulariaceae (Verbascum sinaiticum Benth.).

Family: Zygophyllacaea (Fagonia mollis Del., Peganum harmala L.).

For the studied plant, Alkanna orientalis, a great number of it has been flourished due to overgraze and human cutting effects (Moustafa, 2001). Field observations indicated that many species besides Alkanna orientalis are listed as by-products of grazing intensity such as Teucrium polium, Origanum syriacum, Andrachne espete, A. telephioides, Verbascum species and Onopordum ambiguum. However, Alkanna is the first plant commencing its vegetation at early fall (October) and start early flowering in March (Moustafa, 2001). Although,
Alkanna is not a complete edible plant (due to that dense spiny hairs on leaves) and is not collected by Bedouins but still animals grazed the appropriate parts of Alkanna due to its early flowering behaviour. In spite of all these condition Alkanna plant showed less dynamic population due to the change in climatic condition in the last decade where rainfall was less. In agreement with many earlier studies (Moustafa, 1990; Moustafa and Zaghloul, 1993, 1996; Zaghloul, 1997; Moustafa, 2001) our data prove that soil moisture and organic matter were the most factors affecting the high dominance of Alkanna in study area. Moisture in the form of rainfall is the most decisive factor controlling plant productivity, distribution, and life form of the studied plant. The ecological conditions of the study area confirm the less dynamic population of Alkanna orientalis.

In general, the total amount of precipitation falling in an ecosystem does not always give a clear picture of the availability of moisture to the plants. The precipitation type, intensity, annual variation, soil deposits, topography, and vegetation physiognomy influences the availability of moisture furnished by precipitation to the plants. The factorial approach to analyse the plant distribution emphasizes that distribution is controlled by the interaction between several environmental factors capable of independent variation (Moustafa et al., 2017). The ordination analysis emphasized that soil texture (fine sand fraction), moisture content organic matter of the soil and boulders are the most significant factors controlling the dominance of Alkanna orientalis in two main locations. Predominantly, the effect of the nature of soil surface (boulders, stones, cobbles and gravel) and its roughness is related to its capacity for water storage (Moustafa and Zaghloul, 1996). Therefore, management strategies for the protection and conservation of natural habitats such as the ecosystem community dominated by Alkanna species are in need. This can be done through the embryological research for the period of seed development to enhance their reproductive capacity. Meanwhile, studying the ability of Alkanna species to reproduce asexually along with the sexually one (facultative apomicts) may increase its adaptability and expands its range of distribution.

\section{REFERENCES}

AFZAL, M. AND TOFEEQ, M. (1975). Isolation of Shikonin angelate from root of Alkanna hirsutissima. J. Chem. Soc., 29: 1334-1335.

ABDEL-GELIL, O. E., ATWA, N. A., MOUSTAFA, A. R. A., \& MANSOUR, S. R. (2019). Alkanna Species: A Promising Herbal Medicine and its Uses. Journal of Food Science and Nutrition Research, 2, 309-315.

HAMMOUDA, F.M., ISMAIL, S.I., HASSAN, N.M., TAWFIQ, W.A., AND KAMEL A. (1992): Pyrrolizidine alkaloids from Alkanna orientalis (L.) 
Boiss (a medicinal plant from Egypt). Qatar University. Science Journal, 12: 80-82.

HARPER, J.L., 1983. Population Biology of Plants. Academic Press, London.

HEYWOOD, V.H., D.M. MOORE, I.B.K. RICARDSON AND W.T. SREARN, 1978. Flowering Plants of the World. Oxford University Press, UK, London, Pages: 828.

LEV, E., AMAR, Z. (2000). Ethnopharmacological survey of traditional drugs sold in Israel at the end of the 20th century. Journal of Ethnopharmacology, 72(1-2), 191-205.

MITA, G., GERARDI, C., MICELI, A., BOLLINI, R., AND DE LEO, P. (1994). Pigment production from in vitro cultures of Alkanna tinctoria Tausch. Plant cell reports, 13(7), 406-410.

MOUSTAFA, A. R. A., AND KLOPATEK, J. M. (1995). Vegetation and landforms of the Saint Catherine area, southern Sinai, Egypt. Journal of arid Environments, 30(4), 385-395.

MOUSTAFA, A. A., AND ZAGHLOUL, M. S. (1993). Environmental factors affecting the distribution of plant species in gorge habitats, South Sinai, Egypt. In Proc. 1st Conf. Egypt. Hung. Env. Egypt (pp. 268-274).

MOUSTAFA, A. E. R. A., AND ZAGHLOUL, M. S. (1996). Environment and vegetation in the montane Saint Catherine area, South Sinai, Egypt. Journal of Arid Environments, 34(3), 331-349.

MOUSTAFA, A. R. A., and KAMEL, M. (1995). Ecological notes on the floristic composition and endemic species of Saint Catherine area, South Sinai, Egypt. Egyptian Journal of Botany, 35, 179200.

MOUSTAFA, A.A., 1990. Environmental gradients and species distribution on Sinai Mountains. Ph.D. Thesis, Botany Department, Faculty of Science, Suez Canal University, Egypt.

MOUSTAFA, A.R.A., 2001. Impact of grazing intensity and human disturbance on the population dynamics of Alkanna orientalis growing in Saint Catherine Mountains, South Sinai, Egypt. Pak. J. Biol. Sci., 4: 1020-1025.

MOUSTAFA, A. A. (2002). Distribution Behaviour and Seed Germination of Alkanna orientalis Grow- ing in Saint Catherine Protectorate. Pakistan Journal of Biological Sciences, 5, 427-433.

MOUSTAFA, A. A., ZAGHLOUL, M. S., MANSOUR, S. R., ALSHARKAWY, D. H., \& ALOTAIBI, M. (2017). Long term monitoring of Rosa arabica populations as a threatened species in south Sinai, Egypt. J. Biodivers. Endanger. Species, 5, 197.

NING, W., ZHAO, Q., XIA, Z. AND CAO, R. (1994): Effect of fungal elicitor on Shikonin derivatives formation in Onosma paniculation cell cultures. Acta Phytophysiol. Sin. 20: 325-331.

PAPAGEORGIOU, B., 1980. Isolation of two new Alkanine enters from Alkanna tinctoria. J. Plantae Med., 30: 81-84.

SAID, R. (1962). The geology of Egypt: Elsevier Sci. Pub. Co., Amsterdam, 377.

SEMIDA, F. M. (1994). Insect-plant coevolution in the Sinai desert ecosystem (PhD Thesis, Suez Canal University, Ismailia, Egypt).

TÄCKHOLM, V., 1974. Students Flora of Egypt III. Faculty Science, Cairo University, Egypt.

TANAKA, Y. AND ODANI, T. (1972): Pharmacodynamic study on "shiunko". 1Anlibacterial effect of shiunko Yakugaku Zasshi 92: 525-530.

VORVAGALIS, A.G., 1972. Spectroscopic study of wax Isolated from alkanna tinctoria. J. Chem. Chron.

WASHITANI, I., KABAYA, H. (1988). Germination responses to temperature responsible for the seedling emergence seasonality ofPrimula sieboldii E. Morren in its natural habitat. Ecological Research, 3(1), 9-20.

ZAGHLOUL, M.S., 1997. Ecological studies on some endemic plant species in South Sinai, Egypt. M.Sc. Thesis, Botany Department Faculty Science, Suez Canal University, Ismailia, Egypt.

ZANNOU, O., AND KOCA, I. (2020). Optimization and stabilization of the antioxidant properties from Alkanet (Alkanna tinctoria) with natural deep eutectic solvents. Arabian Journal of Chemistry,13(8), 6437-6450. 
أثر تغير المناخ على سلوك وتوزيع نبات الاكانا اورينتالس في ساتت كاترين، جنوب سيناء، مصر

\author{
عبدالرؤوف مصطفى- سميرة منصور \\ قسم النبات، كلية العلوم، جامعة قناة السويس، الإسماعيلية منصورة
}

\title{
الملخص العربـــي
}

يعتبر نبات الكانا أورينتاليس من النباتات الطبية التي لها أهمية كبيرة في الطب التقليدي. ويعتبر تواجد، توزيع وتعداد هذه

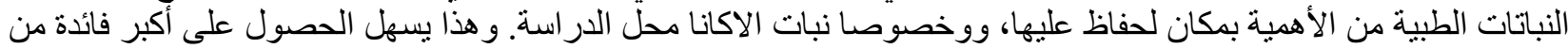

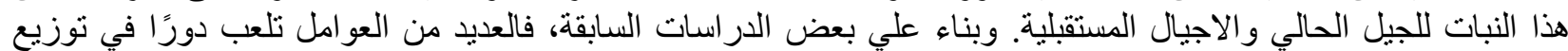

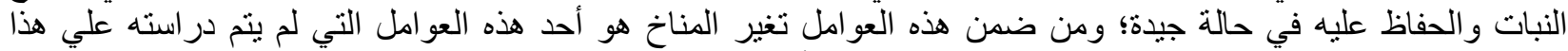

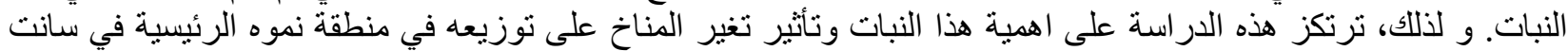

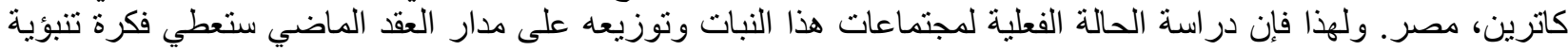

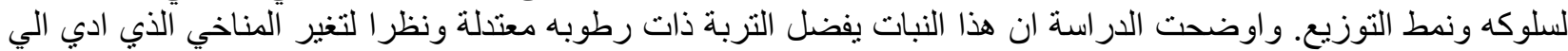

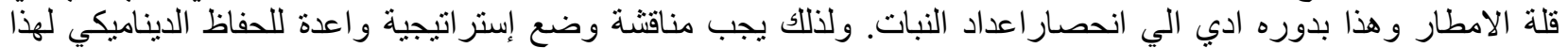

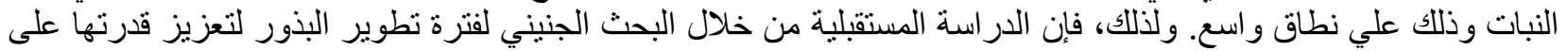

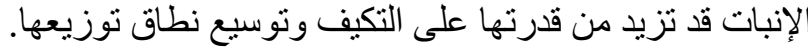

